\title{
Thermal alteration of soil organic matter properties: a systematic study to infer response of Sierra Nevada climosequence soils to forest fires
}

\author{
Samuel N. Araya ${ }^{1}$, Marilyn L. Fogel ${ }^{1,2}$, and Asmeret Asefaw Berhe ${ }^{1,2}$ \\ ${ }^{1}$ Environmental Systems Graduate Group, University of California, Merced, CA 95343, USA \\ ${ }^{2}$ Life and Environmental Sciences Unit, University of California, Merced, CA 95343, USA \\ Correspondence to: Samuel N. Araya (saraya@ucmerced.edu)
}

Received: 24 August 2016 - Published in SOIL Discuss.: 1 September 2016

Revised: 9 January 2017 - Accepted: 11 January 2017 - Published: 6 February 2017

\begin{abstract}
Fire is a major driver of soil organic matter (SOM) dynamics, and contemporary global climate change is changing global fire regimes. We conducted laboratory heating experiments on soils from five locations across the western Sierra Nevada climosequence to investigate thermal alteration of SOM properties and determine temperature thresholds for major shifts in SOM properties. Topsoils ( 0 to $5 \mathrm{~cm}$ depth) were exposed to a range of temperatures that are expected during prescribed and wild fires $\left(150,250,350,450,550\right.$, and $\left.650{ }^{\circ} \mathrm{C}\right)$. With increase in temperature, we found that the concentrations of carbon (C) and nitrogen $(\mathrm{N})$ decreased in a similar pattern among all five soils that varied considerably in their original SOM concentrations and mineralogies. Soils were separated into discrete size classes by dry sieving. The $\mathrm{C}$ and $\mathrm{N}$ concentrations in the larger aggregate size fractions $(2-0.25 \mathrm{~mm})$ decreased with an increase in temperature, so that at $450^{\circ} \mathrm{C}$ the remaining $\mathrm{C}$ and $\mathrm{N}$ were almost entirely associated with the smaller aggregate size fractions $(<0.25 \mathrm{~mm})$. We observed a general trend of ${ }^{13} \mathrm{C}$ enrichment with temperature increase. There was also ${ }^{15} \mathrm{~N}$ enrichment with temperature increase, followed by ${ }^{15} \mathrm{~N}$ depletion when temperature increased beyond $350{ }^{\circ} \mathrm{C}$. For all the measured variables, the largest physical, chemical, elemental, and isotopic changes occurred at the mid-intensity fire temperatures, i.e., 350 and $450^{\circ} \mathrm{C}$. The magnitude of the observed changes in SOM composition and distribution in three aggregate size classes, as well as the temperature thresholds for critical changes in physical and chemical properties of soils (such as specific surface area, $\mathrm{pH}$, cation exchange capacity), suggest that transformation and loss of SOM are the principal responses in heated soils. Findings from this systematic investigation of soil and SOM response to heating are critical for predicting how soils are likely to be affected by future climate and fire regimes.
\end{abstract}

\section{Introduction}

Fire is a common, widespread global phenomenon (Bowman et al., 2009) that conditions the dynamics of soil and soil organic matter (SOM). Vegetation fires burn an estimated 300 to 400 million ha of land globally every year (FAO, 2005). In the US alone, over 80000 fires were reported in 2014 including about 63000 wildland fires and 17000 prescribed burns that burned over 1.5 million and 970000 ha of land, respectively (National Interagency Fire Center, 2015). In the Sierra Nevada, vegetation fires have a major influence on the landscape. Ecological functions such as plant regeneration, habitat revitalization, biomass accumulation, and nutrient cycling are influenced by fires (McKelvey et al., 1996). Historically most fires were caused by lightning fires, and vegetation fires play an important role in maintaining the health of many ecosystems around the world (Harrison et al., 2010). In recent decades, anthropogenic activities have become major causes of vegetation fires (Caldararo, 2002). Moreover, climate and climatic variations exert a strong influence on the distribution, frequency, and severity of fires (Harrison et al., 2010). Significant changes in global fire regimes are anticipated because of climate change, including increased frequency of fires in the coming decades (Pechony and Shindell, 
2010; Westerling et al., 2006). However, our understanding of how climate change and changes in fire regimes will interact to influence topsoils in fire-affected ecosystems is limited.

In addition to combustion of aboveground biomass and alteration of vegetation dynamics, fires also affect the physical, chemical, and biological properties of soils (Certini, 2005; González-Pérez et al., 2004; Mataix-Solera et al., 2011). The degree of alteration caused by fires depends on the fire intensity and duration, which in turn depend on factors such as the amount and type of fuels, properties of aboveground biomass, air temperature and humidity, wind, topography, and soil properties such as moisture content, texture, and SOM content (DeBano et al., 1998). The first-order effects of fire on soil are caused by the input of heat, causing extreme soil temperatures in topsoil (Badía and Martí, 2003b; Neary et al., 1999), which results in loss and transformation of SOM, changes in soil hydrophobicity, changes in soil aggregation, loss of soil mass, and addition of charred material and other combustion products (Albalasmeh et al., 2013; Araya et al., 2016; Mataix-Solera et al., 2011; Rein et al., 2008; Santos et al., 2016).

The duration of burning regulates the amount of energy transferred through the soil. Fires with longer residence time and lower temperature typically impact the soil and SOM more than fires with shorter residence time that burn at a higher temperature (Frandsen and Ryan, 1986; GonzálezPérez et al., 2004). Penetration of heat down a soil profile depends on intensity and duration of fire as well as the thermal conductivity of the soil (Steward et al., 1990). Soils have low thermal conductivity and only experience extreme temperatures in the top few centimeters of soil during fires. For example, in short-duration or low-severity fires temperatures typically reach only $100-150^{\circ} \mathrm{C}$ at $5 \mathrm{~cm}$ depth, with no significant change of temperature at $30 \mathrm{~cm}$ depth (DeBano, 2000; Janzen and Tobin-Janzen, 2008).

Fire has multiple complex effects on carbon (C) dynamics in soil. Wildfires alone lead to the release of up to 4.1 $\mathrm{PgC}$ year $^{-1}$ to the atmosphere in the form of carbon dioxide, with an additional 0.05 to $0.2 \mathrm{PgC}_{\text {year }}{ }^{-1}$ added to the soil as black or pyrogenic carbon ash (Singh et al., 2012). The changes in SOM characteristics due to combustion include reduced solubility of organic matter (OM) due to loss of external oxygen containing functional groups; reduced chain length of fatty acids, alcohols, and other alkyl compounds; higher aromaticity due to transformation of carbohydrates and lipids; production of pyrogenic carbon; formation of heterocyclic nitrogen $(\mathrm{N})$ compounds; and macromolecular condensation of humic substances (González-Pérez et al., 2004). In the long term, fires can affect soils by altering and removing vegetation and topsoil biomass and increasing soil erodibility (Carroll et al., 2007; DeBano, 1991), subsequently leading to a shift in plant and microbial populations (Janzen and Tobin-Janzen, 2008).
The aim of this study is to determine the effects of heating temperatures on important SOM properties. We used a laboratory heating experiment on five soils from a wellcharacterized climosequence in the western Sierra Nevada mountain range (Dahlgren et al., 1997). We analyzed changes in SOM quantity and quality following heating treatment with the aim to (1) determine magnitudes of change in SOM properties associated with different fire heating temperatures, (2) identify critical thresholds for these changes, and (3) infer the implications of changing climate on topsoil SOM properties that might experience changing fire regime. This study aims to contribute to the systematic evaluation and development of the ability to predict the effect of fires of different intensities on soil properties under changing climate and fire regimes.

\section{Materials and methods}

Following the laboratory heating of five soils from the western Sierra Nevada to temperatures ranging from 150 to $650^{\circ} \mathrm{C}$, we analyzed changes in SOM quality and quantity. We measured the changes in $\mathrm{C}$ and $\mathrm{N}$ concentration in the soil and changes in the distribution of $\mathrm{C}$ and $\mathrm{N}$ to different aggregate size classes. We also measured changes in isotopic composition of ${ }^{13} \mathrm{C}$ and ${ }^{15} \mathrm{~N}$ in the soils and in the different aggregate size classes. Changes in SOM quality was analyzed using Fourier transform infrared (FTIR) spectroscopy of soils. Description of the study site is given in Sect. 2.1 and details of the methods used are given in Sect. 2.2 to 2.4.

\subsection{Study site and soil description}

For this study, we collected soils from five sites across an elevation transect along the western slope of the central Sierra Nevada, California (Fig. 1); the sites were previously characterized by Dahlgren et al. (1997). We selected four forested sites that are likely to experience forest fires and a fifth lowerelevation grassland site. The thermal alterations in bulk soil physical and chemical properties from the same study soils were previously reported in Araya et al. (2016).

All the sites have a Mediterranean climate characterized by warm-to-hot, dry summers and cool-to-cold, wet winters. Mean annual air temperature ranges from $16.7^{\circ} \mathrm{C}$ at the lowest site located at $210 \mathrm{~m}$ a.s.l. to $3.9^{\circ} \mathrm{C}$ at the highest elevation site at an elevation of $2865 \mathrm{~m}$ a.s.l. Annual precipitation ranges from $33 \mathrm{~cm}$ at the lowest site to $127 \mathrm{~cm}$ at the highest site (Dahlgren et al., 1997; Rasmussen et al., 2007) (Table 1).

The lower elevation woodlands of the Sierra Nevada experience less frequent fires than further upslope and the fires are often fast moving and lower severity (Skinner and Chang, 1996). At the middle-elevation zone of the Sierran forest, the mixed conifer zones, frequent fires are low to moderate severity at lower altitudes, but fire frequency generally increases with altitude towards the upper elevation of the mixed conifer forest (Caprio and Swetnam, 1993). Fires are infre- 

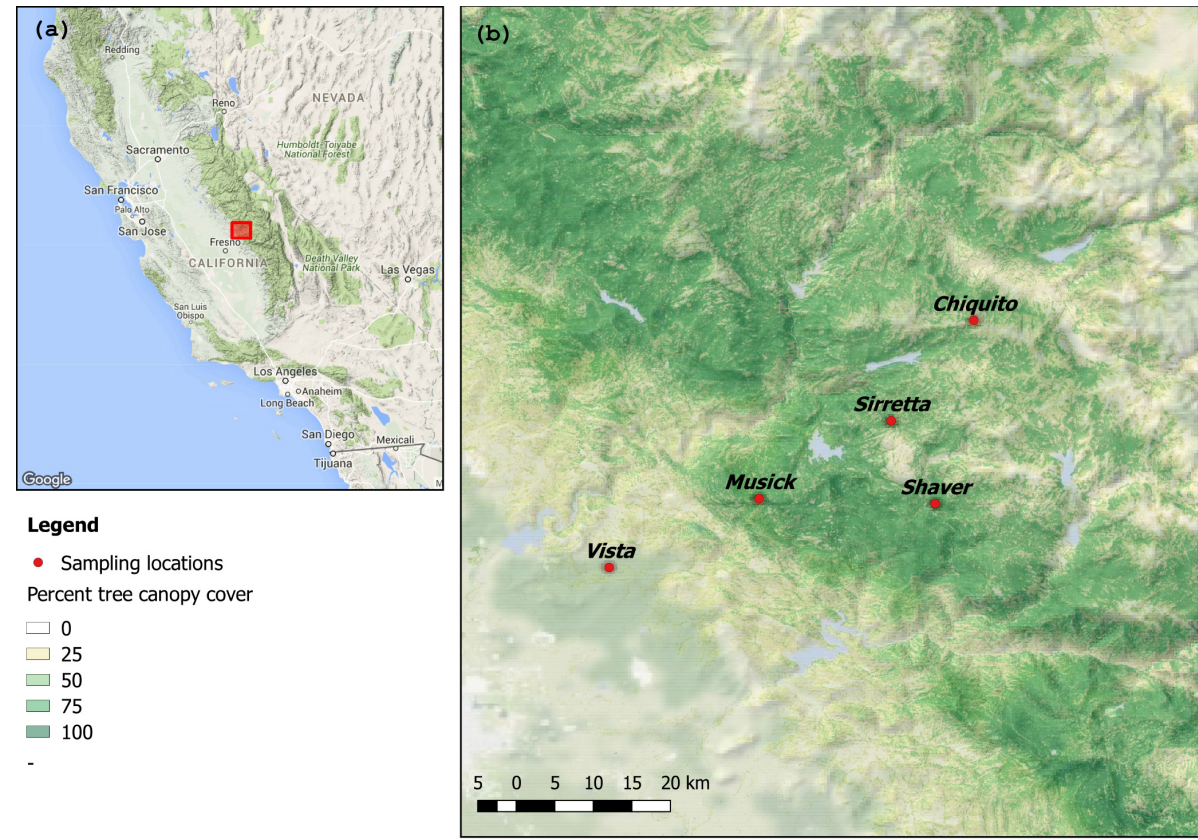

Figure 1. (a) Location of the sampling site on the western slopes of the Sierra Nevada, California, and (b) map of the five sampling locations and percent tree canopy cover (US Geological Survey, 2014).

Table 1. Soil classification and site description for the five sites along an elevational transect of the western slopes of the Sierra Nevada (adapted from Dahlgren et al., 1997).

\begin{tabular}{|c|c|c|c|c|c|c|c|}
\hline $\begin{array}{l}\text { Soil } \\
\text { series }\end{array}$ & Elevation (m) & Ecosystem & $\operatorname{MAT}^{\mathrm{a}}\left({ }^{\circ} \mathrm{C}\right)$ & $\mathrm{MAP}^{\mathrm{b}}(\mathrm{cm})$ & Precip $^{c}$ & $\begin{array}{l}\text { Dominant vegetation (listed } \\
\text { in order of dominance) }\end{array}$ & Soil taxonomy (family) \\
\hline Vista & 210 & Oak woodland & 16.7 & 33 & Rain & $\begin{array}{l}\text { Annual grasses, } \\
\text { Quercus douglasii, } \\
\text { Quercus wislizeni }\end{array}$ & $\begin{array}{l}\text { Coarse-loamy, mixed, superac- } \\
\text { tive, thermic; Typic Haplox- } \\
\text { erepts }\end{array}$ \\
\hline Musick & 1384 & $\begin{array}{l}\text { Oak-mixed } \\
\text { conifer forest }\end{array}$ & 11.1 & 91 & Rain & $\begin{array}{l}\text { Pinus ponderosa, } \\
\text { Calocedrus decurrens, } \\
\text { Quercus kelloggii, } \\
\text { Chamaebatia foliolosa }\end{array}$ & $\begin{array}{l}\text { Fine-loamy, mixed, semiactive, } \\
\text { mesic; Ultic Haploxeralf }\end{array}$ \\
\hline Shaver & 1737 & $\begin{array}{l}\text { Mixed conifer } \\
\text { forest }\end{array}$ & 9.1 & 101 & Snow & $\begin{array}{l}\text { Abies concolor, } \\
\text { Pinus lambertiana, } \\
\text { Pinus ponderosa, } \\
\text { Calocedrus decurrens }\end{array}$ & $\begin{array}{l}\text { Coarse-loamy, mixed, superac- } \\
\text { tive, mesic; Humic Dystrox- } \\
\text { erepts }\end{array}$ \\
\hline Sirretta & 2317 & $\begin{array}{l}\text { Mixed conifer } \\
\text { forest }\end{array}$ & 7.2 & 108 & Snow & $\begin{array}{l}\text { Pinus jeffreyi, } \\
\text { Abies magnifica, } \\
\text { Abies concolor }\end{array}$ & $\begin{array}{l}\text { Sandy-skeletal, mixed, frigid; } \\
\text { Dystric Xerorthent }\end{array}$ \\
\hline Chiquito $^{\mathrm{d}}$ & 2865 & $\begin{array}{l}\text { Subalpine } \\
\text { mixed conifer } \\
\text { forest }\end{array}$ & 3.9 & 127 & Snow & $\begin{array}{l}\text { Pinus contorta murrayana, } \\
\text { Pinus monticola, } \\
\text { Lupinus } \text { species }\end{array}$ & $\begin{array}{l}\text { Sandy-skeletal, mixed; Entic } \\
\text { Cryumbrept }\end{array}$ \\
\hline
\end{tabular}

${ }^{a}$ Mean annual air temperature, calculated from regression equation of Harradine and Jenny (1958). ${ }^{b}$ Mean annual precipitation. ${ }^{\mathrm{c}}$ Dominant form of precipitation. ${ }^{\mathrm{d}}$ Tentative soil series.

quent and low severity within the high altitude, subalpine zone of the Sierra Nevada (Skinner and Chang, 1996).

Soils from the lowest elevation site, Vista series soils ( $210 \mathrm{~m}$ a.s.1.), fall within the oak woodland zone (elevations $<1008 \mathrm{~m}$ a.s.l.). This is the only soil in our study that does not have an O-horizon. The soil has dense annual grass cover and its A-horizon SOM originates mainly from root turnover. The Musick series soils (1384 m a.s.l.) lie within oak-mixed conifer forest (1008-1580 ma.s.1.) and mixed conifer forest (1580-2626 $\mathrm{m}$ a.s.l.). These soils receive the highest litter fall biomass. The Shaver and Sirretta series soils (1737 and $2317 \mathrm{~m}$ a.s.l., respectively) fall within the mixed conifer forest range zone, while the Chiquito series soils ( $2865 \mathrm{~m}$ a.s.l.) lie within the subalpine mixed conifer forest range (2626$3200 \mathrm{~m}$ a.s.l.). These soils have lower litter fall compared 
Table 2. Bulk density, water content, $\mathrm{pH}, \mathrm{C}$ concentration, cation exchange capacity (CEC), specific surface area (SSA), and particle size distribution for the five soils (mean \pm standard error, $n=3$ ).

\begin{tabular}{|c|c|c|c|c|c|c|c|c|c|}
\hline \multirow[t]{2}{*}{$\begin{array}{l}\text { Soil series } \\
\text { and elevation } \\
\text { (m) }\end{array}$} & \multirow[t]{2}{*}{$\begin{array}{r}\text { Bulk } \\
\text { density } \\
\left(\mathrm{g} \mathrm{cm}^{-3}\right)\end{array}$} & \multirow[t]{2}{*}{$\begin{array}{r}\text { Gravimetric } \\
\text { water content } \\
(\%)\end{array}$} & \multirow[t]{2}{*}{$\begin{array}{r}\mathrm{pH} \\
\left(\mathrm{CaCl}_{2}\right)\end{array}$} & \multirow[t]{2}{*}{$\begin{array}{r}\text { Carbon } \\
(\%)\end{array}$} & \multirow[t]{2}{*}{$\begin{array}{r}\text { CEC } \\
\left(\mathrm{cmol}_{\mathrm{c}} \mathrm{kg}^{-1}\right)\end{array}$} & \multirow[t]{2}{*}{$\begin{array}{r}\text { SSA } \\
\left(\mathrm{m}^{2} \mathrm{~g}^{-1}\right)\end{array}$} & \multicolumn{3}{|c|}{$\begin{array}{c}\text { Particle size } \\
\text { distribution }^{\mathrm{a}} \\
(\%)\end{array}$} \\
\hline & & & & & & & Sand & Silt & Clay \\
\hline Vist & $6 \pm$ & \pm 0 & $3=$ & $151+02$ & 40 & $1.75=$ & 79 & 11 & 10 \\
\hline Music & \pm & & $67 \pm$ & $56 \pm 0.8$ & $.20 \pm$ & $4.98=$ & 60 & 27 & 15 \\
\hline Shaver (1737) & $98 \pm 0.06$ & \pm 1.1 & $4.85 \pm 0.3$ & $2.84 \pm 0.2$ & $10.67 \pm 2.1$ & $3.08 \pm 0.3$ & 80 & 15 & $\tau$ \\
\hline Sirretta (231 & $1.18+8$ & & $4.54 \pm 0.1$ & $4.74 \pm$ & $12.23 \pm$ & $6.63 \pm 0.8$ & 80 & 15 & J \\
\hline Chiquito (2865) & $1.17 \pm 0.03$ & $6.1 \pm 1.9$ & $3.96 \pm 0.1$ & $4.10 \pm 0.2$ & $6.03 \pm 1.8$ & $1.00 \pm 0.04$ & 80 & 16 & 4 \\
\hline
\end{tabular}

a Particle size distribution of topsoil profile from Dahlgren et al. (1997): Vista (0-14 cm), Musick (0-29 cm), Shaver (0-4 cm), Sirretta (0-6 cm), and Chiquito (0-6 cm).

to the lower elevation soils (van Wagtendonk and FitesKaufman, 2006).

The western slope of the central Sierra Nevada presents a remarkable climosequence of soils that developed under similar granitic parent material and are located in landscapes of similar age, relief, slope, and aspect (Trumbore et al., 1996), with significant developmental differences attributed to climate. The soils at mid-elevation range (1000 to $2000 \mathrm{~m}$ a.s.l.) tend to be highly weathered, while soils at high and low elevations are relatively less developed (Dahlgren et al., 1997; Harradine and Jenny, 1958; Huntington, 1954; Jenny et al., 1949). Among the most important changes in soil properties along the climosequence are changes in soil organic carbon (SOC) concentration, base saturation, mineral desilication, and hydroxyl-Al interlayering of $2: 1$ layer silicates. Soil $\mathrm{pH}$ generally decreases with elevation and the concentrations of clay and secondary iron oxides show a step change at the elevation of the present-day average effective winter snow line, i.e., $1600 \mathrm{~m}$ elevation (Tables 1 and 2) (California Department of Water Resources, 1952-1962; Dahlgren et al., 1997).

\subsection{Experimental design and sample collection}

Triplicate samples ( 0 to $5 \mathrm{~cm}$ depth) were collected at the five sites, approximately $10 \mathrm{~m}$ apart from each other. Any overlaying organic layer was removed prior to sampling so that only mineral soil was collected. The soils were air dried at room temperature and passed through a $2 \mathrm{~mm}$ sieve. Prior to furnace heating, the soils were oven dried at $60^{\circ} \mathrm{C}$ overnight. Soil bulk density and field soil moisture were determined from separate undisturbed core samples collected from each site (Table 2).

Subsamples from each soil were heated in a muffle furnace to one of six selected maximum temperatures $(150,250,350$, 450,550 , and $650^{\circ} \mathrm{C}$ ). To ensure uniform soil heating and reduce formation of heating gradient inside, the soils were packed $1 \mathrm{~cm}$ high in $7 \mathrm{~cm}$ diameter porcelain flat capsule crucibles. Oxygen supply was not limited during the heat- ing - the volume of soil sample to volume air in the furnace was approximately $1: 50$. Furnace temperature was ramped at a rate of $3{ }^{\circ} \mathrm{C} \mathrm{min}^{-1}$ and soils were exposed to the maximum temperature for $30 \mathrm{~min}$. Once cooled to touch, soils were stored in airtight polyethylene bags prior to analysis.

The six heating temperatures were selected to correspond with fire intensity categories that are based on maximum surface temperature (DeBano et al., 1977; Janzen and TobinJanzen, 2008; Neary et al., 1999), that is, low intensity (150 and $250^{\circ} \mathrm{C}$ ), medium intensity $\left(350\right.$ and $450^{\circ} \mathrm{C}$ ), and high intensity $\left(550\right.$ and $\left.650^{\circ} \mathrm{C}\right)$. These fire intensity classes generally correspond with thresholds for important thermal reactions in soils observed by differential thermal analyses (Giovannini et al., 1988; Soto et al., 1991; Varela et al., 2010). A heating rate of $3^{\circ} \mathrm{C} \mathrm{min}^{-1}$ is preferred in laboratory fire simulation experiments (Giovannini et al., 1988; Terefe et al., 2008; Varela et al., 2010); the slow heating rate prevents sudden combustion when soil ignition temperature is reached at about $220^{\circ} \mathrm{C}$ (Fernández et al., 1997, 2001; Varela et al., 2010). The samples were exposed to the maximum set temperature for a period of $30 \mathrm{~min}$. This length of time ensures that the entire sample is uniformly heated at the set temperature and is in keeping with the wide majority of similar laboratory soil heating experiments (for example Badía and Martí, 2003a; Fernández et al., 2001; Giovannini, 1994; Varela et al., 2010; Zavala et al., 2010). The duration of soil heating under vegetation fires is highly varied and not uniform across landscape (Parsons et al., 2010). The same heating procedure was used for all the soils so that it would be possible to compare how the soils from different climate regimes are likely to respond to the fires.

\subsection{Laboratory analysis}

Dry-aggregate size distribution was measured by sieving. Samples were dry sieved into three aggregate size classes: $2-0.25 \mathrm{~mm}$ (macroaggregates), $0.25-0.053 \mathrm{~mm}$ (microaggregates), and $<0.053 \mathrm{~mm}$ (silt- and clay-sized particles or composites). These aggregate size classes were selected to enable 
comparison with other studies that investigated the effect of different natural and anthropogenic properties on soil aggregate dynamics and aggregate-protected organic matter (Six et al., 2000).

$\mathrm{C}$ and $\mathrm{N}$ concentrations and stable isotope ratios were measured using an elemental combustion system (Costech ECS 4010 CHNSO Analyzer, Costech Analytical Technologies, Valencia, CA, USA) that was interfaced with a mass spectrometer (DELTA V Plus Isotope Ratio Mass Spectrometer, Thermo Fisher Scientific, Inc., Waltham, MA, USA). For the analyses, air-dried soil samples were ground to powder consistency on a ball mill (8000M Mixer/Mill, with a $55 \mathrm{~mL}$ tungsten carbide vial, SPEX SamplePrep, LLC, Metuchen, NJ, USA) and oven dried at $60^{\circ} \mathrm{C}$ for over $36 \mathrm{~h}$. This lower temperature and longer duration of oven drying was used to avoid possible heating-related $\mathrm{C}$ or $\mathrm{N}$ changes that might occur if drying was done at $105^{\circ} \mathrm{C}$ (Kaiser et al., 2015). The $\mathrm{C}$ and $\mathrm{N}$ concentration results were corrected for moisture by oven drying subsamples at $105^{\circ} \mathrm{C}$ overnight. The $\mathrm{C}$ and $\mathrm{N}$ concentration results were corrected by adjusting for moisture as $W_{\text {adj }}=W \times\left(100-W_{\mathrm{m}}\right)$, where $W_{\text {adj }}$ is the adjusted percent concentration, $W$ is the concentration before moisture adjustment, and $W_{\mathrm{m}}$ is the percent moisture content. All concentration changes resulting from moisture adjustment were a decrease of less than $1 \%$ of the value. The stable isotope ratios are presented using the $\delta$ notation (per mill, \%o) as $\delta^{13} \mathrm{C}$ and $\delta^{15} \mathrm{~N}$ calculated as $\delta=\left[\left(R_{\text {sample }}-R_{\text {standard }}\right) / R_{\text {standard }}\right] \times 1000 \%$, where $R$ is ratio of ${ }^{13} \mathrm{C}$ to ${ }^{12} \mathrm{C}$ for $\delta^{13} \mathrm{C}$ and ${ }^{15} \mathrm{~N}$ to ${ }^{14} \mathrm{~N}$ for $\delta^{15} \mathrm{~N}$. The standards used for analyses are atmospheric $\mathrm{N}_{2} \delta^{15} \mathrm{~N}$ and Vienna Pee Dee Belemnite (VPDB) $\delta^{13} \mathrm{C}$.

Bulk soil organic matter composition was analyzed using FTIR spectroscopy on a Bruker IFS 66v/S vacuum FTIR spectrometer (Bruker Biosciences Corporation, Billerica, MA, USA). We used the diffuse reflectance infrared Fourier transform (DRIFT) technique (Ellerbrock and Gerke, 2013; Parikh et al., 2014). Powder samples were dried overnight at $60{ }^{\circ} \mathrm{C}$ and scanned in mid-infrared from 4000 to $400 \mathrm{~cm}^{-1}$. We used non-KBr-diluted samples after preliminary analyses showed that dilution was not necessary. $\mathrm{KBr}$ dilution is not required for soils with low $(<10 \%)$ organic matter concentrations (Ellerbrock and Gerke, 2013; Reeves III, 2003). The FTIR spectrum was collected using $\mathrm{KBr}$ background and was baseline corrected using the rubber band correction method with the default 64 baseline points that is part of the OPUS software (Bruker Corporation, 2009).

\subsection{Statistical analysis}

All quantitative results are expressed as means of three replicates \pm standard error, unless otherwise indicated. Differences in means were tested by analysis of variance (ANOVA) and pairwise comparison of treatments done using Tukey's honest significant difference (HSD) test at $p<0.05$ significance level. The normality of the data and the homogeneity

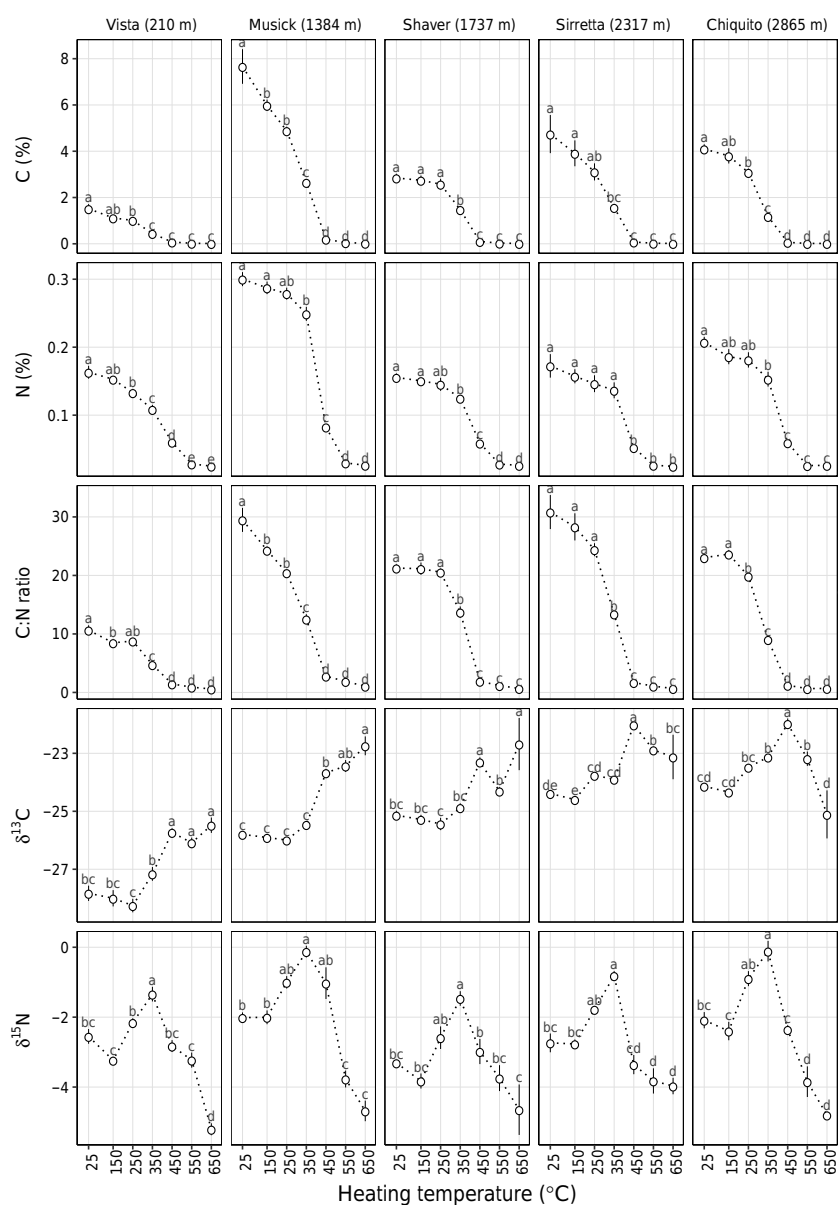

Figure 2. Bulk soil carbon and nitrogen concentrations, $\mathrm{C}: \mathrm{N}$ atomic ratio, and $\delta^{13} \mathrm{C}$ and $\delta^{15} \mathrm{~N}$ isotope (\%o) changes with an increase in heating temperature. Error bars represent standard error, where $n=3$. Different letters represent significantly different means $(p<0.05)$ at each temperature after Tukey's HSD testing.

of variances was checked using Shapiro-Wilk's and Levene's tests, respectively. All statistical analyses were performed using R statistical software (R Core Team, 2014). The Pearson's correlation coefficient was used to examine relationships between $\mathrm{C}$ concentration and changes in soil properties.

\section{Results}

\subsection{Carbon and nitrogen concentration}

The initial concentration of $\mathrm{C}$ ranged from $1.5 \%$ (Vista soil, $210 \mathrm{~m}$ ) to $7.7 \%$ (Musick soils, $1384 \mathrm{~m}$ ). Soil C concentration continuously decreased with increasing temperature. The largest decrease occurred between temperatures of 250 and $450{ }^{\circ} \mathrm{C}$. At $450{ }^{\circ} \mathrm{C}$, all soils lost more than $95 \%$ of their original C. C concentration changes with heating above $450^{\circ} \mathrm{C}$ were small and not statistically significant at $p<0.05$. The $\mathrm{C}: \mathrm{N}$ ratio ranged from 10 (Vista soils, $210 \mathrm{~m}$ ) 
to 29 (Musick soils, $1384 \mathrm{~m}$ ). Following a similar pattern to $\mathrm{C}$ concentration changes, the $\mathrm{C}: \mathrm{N}$ ratio decreased with an increase in heating temperature (Fig. 2).

The loss of $\mathrm{C}$ and $\mathrm{N}$ from soils due to heating showed a similar response among all five soils (Fig. 2). After $250^{\circ} \mathrm{C}$, all the soils lost more than $25 \%$ of their initial C (except Shaver soils that lost only about $10 \%$ ). At $350^{\circ} \mathrm{C}$ all soils lost 50 to $70 \%$ of $\mathrm{C}$. Heating at $450{ }^{\circ} \mathrm{C}$ led to the loss of more than $95 \%$ of their initial $\mathrm{C}$ for all soils in this study. However, the rate of loss of $\mathrm{N}$ was lower than that of $\mathrm{C}$. At temperatures greater than $550^{\circ} \mathrm{C}$ there was 5 to $15 \%$ of soil $\mathrm{N}$ still remaining. Consequently, we observed a decrease in $\mathrm{C}: \mathrm{N}$ ratio with increased heating temperature. All soils continued to lose about $15 \%$ soil $\mathrm{N}$ for every $100^{\circ} \mathrm{C}$ increase and maintained more than $60 \%$ of their $\mathrm{N}$ at heating temperatures up to $350^{\circ} \mathrm{C}$. After heating at $450^{\circ} \mathrm{C}$, all soils lost more than $60 \%$ of their original soil $\mathrm{N}$ and $85 \%$ by $550{ }^{\circ} \mathrm{C}$.

\subsection{Carbon and nitrogen stable isotopes}

The $\delta^{13} \mathrm{C}$ composition of all soils was indicative of $\mathrm{C} 3 \mathrm{veg}-$ etation. Soil $\delta^{13} \mathrm{C}$ composition was most negative at about $-28 \%$ for the lowest elevation Vista site $(210 \mathrm{~m})$, and the value became consistently less negative with an increase in elevation, reaching $-24 \%$ for the highest two sites (i.e., $>2317 \mathrm{~m}$ elevation). For all soils, there was a general trend of $\delta^{13} \mathrm{C}$ enrichment with temperature increase (Fig. 2). The largest change (2.5 to $3.0 \%$ ) occurred at heating temperatures between 250 and $450^{\circ} \mathrm{C}$ for the lower elevation soils and between 150 and $450^{\circ} \mathrm{C}$ for the two highest elevation soils. For the two highest elevation soils, there was a significant $(p<0.05)$ depletion above that temperature. For all soils, except Musick (1384 m) and Shaver (1737 m), the maximum enrichment occurred at $450{ }^{\circ} \mathrm{C}$. All soils showed a similarly patterned $\delta^{15} \mathrm{~N}$ composition change with temperature. The soils were increasingly $\delta^{15} \mathrm{~N}$ enriched with temperature increase up to $350^{\circ} \mathrm{C}$. At temperatures above $350^{\circ} \mathrm{C}$, the soils got more $\delta^{15} \mathrm{~N}$ depleted, with the most negative $\delta^{15} \mathrm{~N}$ occurring at $650^{\circ} \mathrm{C}$ (Fig. 2).

\subsection{Carbon and nitrogen distribution in aggregate size fractions}

$\mathrm{C}$ and $\mathrm{N}$ concentrations as well as ${ }^{13} \mathrm{C}$ - and ${ }^{15} \mathrm{~N}$-stable isotope ratios were measured for individual soil aggregate size class. The analysis was done on samples heated up to a temperature of $450^{\circ} \mathrm{C}$. The concentration of $\mathrm{C}$ and $\mathrm{N}$ in samples heated above $450^{\circ} \mathrm{C}$ was too low to measure significant changes in $\mathrm{C}$ distribution in the different aggregate size classes.

The distribution of $\mathrm{C}$ in the three aggregate size fractions followed the same general pattern with increase in the heating temperatures. The macroaggregate size fraction (2$0.25 \mathrm{~mm}$ ) had the least $\mathrm{C}$ concentration and silt-clay-sized particles $(<0.053 \mathrm{~mm})$ had the largest concentration of $\mathrm{C}$

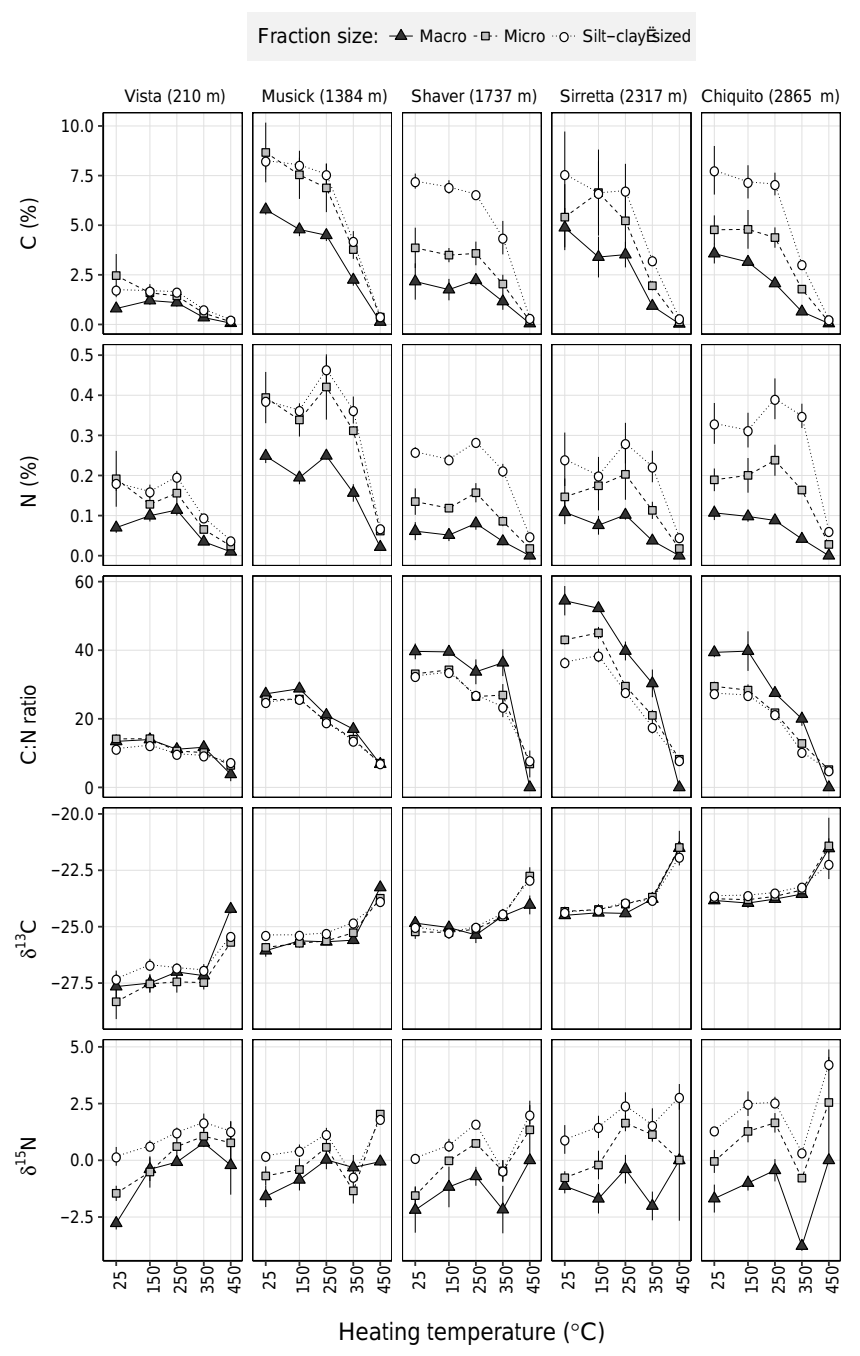

Figure 3. $\mathrm{C}$ and $\mathrm{N}$ concentrations, $\mathrm{C}: \mathrm{N}$ atomic ratio, and $\delta^{13} \mathrm{C}$ and $\delta^{15} \mathrm{~N}$ isotope $(\% \circ)$ changes in macroaggregates $(2-0.25 \mathrm{~mm})$, microaggregates $(0.25-0.053 \mathrm{~mm})$, and silt-clay-sized $(<0.053 \mathrm{~mm})$ aggregates with increase in heating temperature. Error bars represent standard error, where $n=3$.

(Fig. 3). $\mathrm{N}$ concentration for the macroaggregates was below the detection limit at $450^{\circ} \mathrm{C}$ for Chiquito and Sirretta. The change in $\mathrm{C}$ and $\mathrm{N}$ concentration across heating temperature was similar for all soils.

The distribution of $\mathrm{C}$ and $\mathrm{N}$ in different size aggregates did not change noticeably except at $450{ }^{\circ} \mathrm{C}$ where concentration in all three fractions converged to zero. The distribution of $\mathrm{N}$ in the three aggregate size fractions was similar to that of $\mathrm{C}$ and followed a similar pattern across all the heating temperatures. Similarly, the macroaggregate size fraction $(2-0.25 \mathrm{~mm})$ had the least amount of $\mathrm{N}$ concentration, and silt-clay-sized particles $(<0.053 \mathrm{~mm})$ had the largest concentration of N. For Shaver (1737 m), Sirretta (2317 m), and Chiquito $(2865 \mathrm{~m})$ soils, the macroaggregate $\mathrm{N}$ concentration was too low and could not be detected (Fig. 3). The atomic 


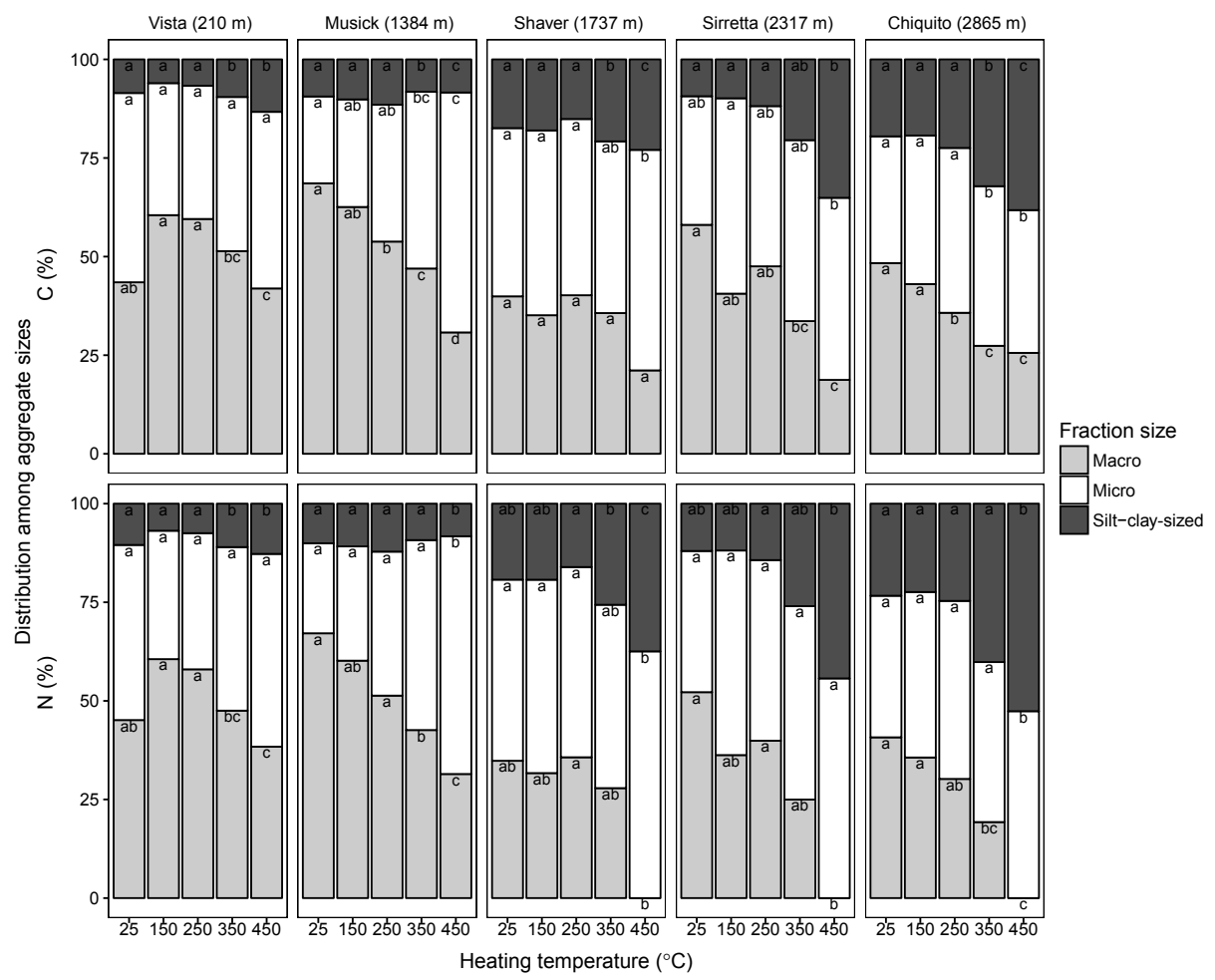

Figure 4. $\mathrm{C}$ and $\mathrm{N}$ distributions in macroaggregates $(2-0.25 \mathrm{~mm})$, microaggregates $(0.25-0.053 \mathrm{~mm})$, and silt-clay-sized $(<0.053 \mathrm{~mm})$ aggregates.

$\mathrm{C}: \mathrm{N}$ ratio generally stayed the same for all soils throughout the temperatures. $\mathrm{C}: \mathrm{N}$ ratio was highest in macroaggregates, which had the lowest $\mathrm{C}$ and $\mathrm{N}$ concentrations, followed by microaggregates and silt-clay sizes for all soils.

The stable isotope composition of ${ }^{13} \mathrm{C}$ was very similar between aggregate sizes, with silt-clay-sized aggregates being slightly more enriched, except for Shaver $(1737 \mathrm{~m})$, which had slightly more enriched macroaggregates. Conversely, the $\delta^{15} \mathrm{~N}$ values showed clear differences among aggregate fractions even though the measured values of $\delta^{15} \mathrm{~N}$ did not change notably with combustion temperatures. $\delta^{15} \mathrm{~N}$ was highest in silt-clay-sized particles and lowest in macroaggregates, with the microaggregates showing intermediate values. The pattern of change in $\delta^{15} \mathrm{~N}$ across combustion temperatures did not affect this order of $\delta^{15} \mathrm{~N}$ values among aggregate fractions. Most of the $\mathrm{C}$ and $\mathrm{N}$ in the soils was associated with the larger macroaggregate and microaggregate fractions. With the exception of Vista $(210 \mathrm{~m})$ soils, the concentrations in macroaggregates continued to decrease with an increase in temperature, and the remaining $\mathrm{C}$ and $\mathrm{N}$ concentrations were distributed between the smaller aggregate fractions (Fig. 4). At $450^{\circ} \mathrm{C}$, most of the $\mathrm{C}$ and $\mathrm{N}$ of the higher altitude soils (Shaver, Sirretta, and Chiquito) was now associated with the silt-clay-sized fractions.

\subsection{FTIR spectroscopy}

Changes in chemical composition of SOM due to heating were analyzed by infrared spectroscopy using the DRIFT technique. The spectra and peaks after contrasting levels of thermal treatments exhibited qualitative similarities among the different soils. FTIR spectra for the soils are shown in Fig. 5. One notable change that occurred in the functional group composition of SOM with heating is the lowered absorbance intensity of aliphatic methylene groups (as represented by the aliphatic $\mathrm{C}-\mathrm{H}$ stretching peak that appears at bands between 2950 and $2850 \mathrm{~cm}^{-1}$ ) at $>250^{\circ} \mathrm{C}$ in all soils. When comparing intensity of peaks at 2910-2930 and $2853 \mathrm{~cm}^{-1}$ wave numbers (from aliphatic methyl and methylene groups, band A) with those at 1653 and $1400 \mathrm{~cm}^{-1}$ (oxygen containing carboxyl and carbonyl groups, band $\mathrm{B}$ ), the decrease in prominence in the aliphatic $\mathrm{C}-\mathrm{H}$ peak occurs early in the heating sequence, while the $\mathrm{C}=\mathrm{O}$ band shows little relative change. In addition, after heating at a temperature of $550^{\circ} \mathrm{C}$, all soils lost the $\mathrm{O}-\mathrm{H}$ stretching peaks (between 3700 and $3200 \mathrm{~cm}^{-1}$ ). In a pattern that is more prominent for the Musick soil that had the highest concentration of $\mathrm{OM}$, the aromatic $\mathrm{C}=\mathrm{C}$ stretch around $1600 \mathrm{~cm}^{-1}$ gets more resolved with increase in heating temperature. This pattern in the $\mathrm{C}=\mathrm{C}$ is visible but not as well resolved in the rest of the soils, especially the Vista soil that showed the least-resolved aromatic $\mathrm{C}=\mathrm{C}$ stretch peak in this region. 

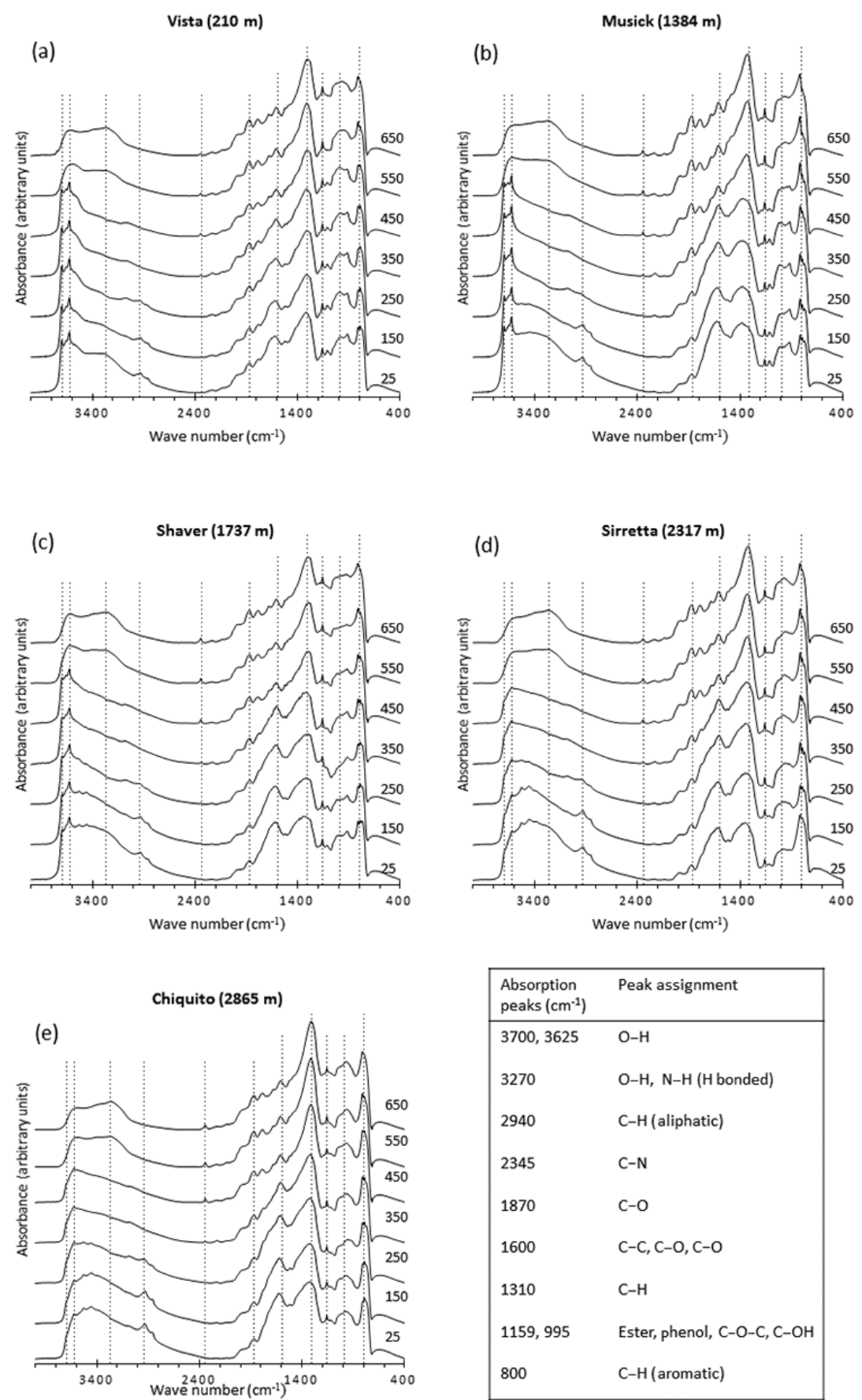

\begin{tabular}{|ll|}
\hline $\begin{array}{l}\text { Absorption } \\
\text { peaks }\left(\mathrm{cm}^{-1}\right)\end{array}$ & Peak assignment \\
\hline 3700,3625 & $\mathrm{O}-\mathrm{H}$ \\
3270 & $\mathrm{O}-\mathrm{H}, \mathrm{N}-\mathrm{H}$ (H bonded) \\
2940 & $\mathrm{C}-\mathrm{H}$ (aliphatic) \\
2345 & $\mathrm{C}-\mathrm{N}$ \\
1870 & $\mathrm{C}-\mathrm{O}$ \\
1600 & $\mathrm{C}-\mathrm{C}, \mathrm{C}-\mathrm{O}, \mathrm{C}-\mathrm{O}$ \\
1310 & $\mathrm{C}-\mathrm{H}$ \\
1159,995 & Ester, phenol, C-O-C, C-OH \\
800 & $\mathrm{C}-\mathrm{H}$ (aromatic) \\
\hline
\end{tabular}

Figure 5. FTIR spectra of the five soils at the different heating temperatures. Heating temperatures, in Celsius, are shown to the right of each spectrum.

\section{Discussion}

\subsection{Changes in SOM concentration, distribution, and composition}

Our results show significant effects of combustion temperature on concentration, distribution, and composition of SOM in topsoils that experience the most intense heating dur- ing vegetation fires. Topsoils have relatively high $\mathrm{OM}$ and low clay content that render them more sensitive to heating since the SOM experiences significant changes during heating. In our study system, the effect of fire heating on SOM ranged from slight distillation (volatilization of minor constituents), typically at temperatures below $150^{\circ} \mathrm{C}$, to charring, which typically starts at temperatures above $350^{\circ} \mathrm{C}$, and 
complete combustion, consistent with findings of previous studies (Badía and Martí, 2003b; Certini, 2005). Our findings also confirmed that regardless of the differences our soils had in mineralogy and other soil physical and chemical properties, the heating treatments (as a proxy for wildfires) led to a consistent decrease in concentration of soil C. This was in agreement with previous studies that showed a decrease in soil C concentration in topsoil after fires (for example Badía et al., 2014; Certini, 2005). However, this loss of C is expected to be restricted to topsoil, while it is expected that the $\mathrm{C}$ concentration in subsoil is likely to remain unchanged or may even increase (for example Dennis et al., 2013; Kavdır et al., 2005) due to incorporation of necromass from surface biomass (Almendros et al., 1990; Knicker et al., 2005).

We observed significant changes in concentration, distribution, and composition of SOM with increasing heating temperature. The steep decline in concentration of $\mathrm{C}$ in soil that we observed in this study is consistent with a decrease of about $25 \% \mathrm{C}$ at $250{ }^{\circ} \mathrm{C}$ and an almost $99 \%$ loss at $450{ }^{\circ} \mathrm{C}$ (Fig. 6). The magnitude of $\mathrm{C}$ loss with heating we observed is similar to the findings of Terefe et al. (2008); and Ulery and Graham (1993), who investigated changes in soil C using artificial heating experiments. Similarly, Giovannini et al. (1988) also found that $\mathrm{OM}$ decrease started at $220^{\circ} \mathrm{C}$ with about $15 \%$ loss of $\mathrm{OM}$ and about $90 \%$ OM loss at $460^{\circ} \mathrm{C}$. Fernández et al. (1997) reported $37 \%$ of SOM loss at $220^{\circ} \mathrm{C}$ and $90 \%$ at $350^{\circ} \mathrm{C}$. Furthermore, along with the change in $\mathrm{C}$ concentration, between $150^{\circ} \mathrm{C}$ and before almost total loss of $\mathrm{C}$ above $450^{\circ} \mathrm{C}$, the SOM went through significant qualitative changes that included decrease in $\mathrm{C}: \mathrm{N}$ ratio, enrichment in $\delta^{13} \mathrm{C}$ isotope, changes in $\delta^{15} \mathrm{~N}$ isotope, and changes in FTIR spectra. Loss of $\mathrm{N}$ after fire heating is the result of combustion and volatilization (Fisher and Binkley, 2000). In this study, we observed that $\mathrm{N}$ is not as significantly reduced until $350{ }^{\circ} \mathrm{C}$, with about $75 \% \mathrm{~N}$ remaining as opposed to a loss of $\mathrm{C}$ concentration greater than $50 \%$ at the same temperature (Fig. 6). Previous studies had shown that moderateto high-intensity fires convert most organic-N into inorganic forms of N, such as ammonium (Certini, 2005; Huber et al., 2013). Ammonium is the immediate combustion product that contributes to formation of nitrate $\left(\mathrm{NO}_{3}^{-}\right)$by nitrification reactions in the weeks or months after a fire. Other studies have shown that a considerable amount of $\mathrm{N}$ is transferred into pyrogenic OM products, to black N (de la Rosa and Knicker, 2011; Knicker, 2010), which would also explain the decrease in the $\mathrm{C}: \mathrm{N}$ ratio. Decrease in the $\mathrm{C}: \mathrm{N}$ ratio with fire heating has previously been observed in both laboratory and field fire studies (Badía and Martí, 2003a; Certini, 2005; Fernández et al., 1997; González-Pérez et al., 2004).

SOM has a $\mathrm{C}$ isotopic composition that reflects the $\delta^{13} \mathrm{C}$ signature of native vegetation. Plants are depleted in $\delta^{13} \mathrm{C}$ relative to atmosphere. The $\delta^{13} \mathrm{C}$ composition for our soils indicated that the dominant source of $\mathrm{OM}$ in all soils was $\mathrm{C} 3$ plant biomass that had an average $\delta^{13} \mathrm{C}$ of $-27 \%$, with the higher-elevation soils having more positive $\delta^{13} \mathrm{C}$ than the
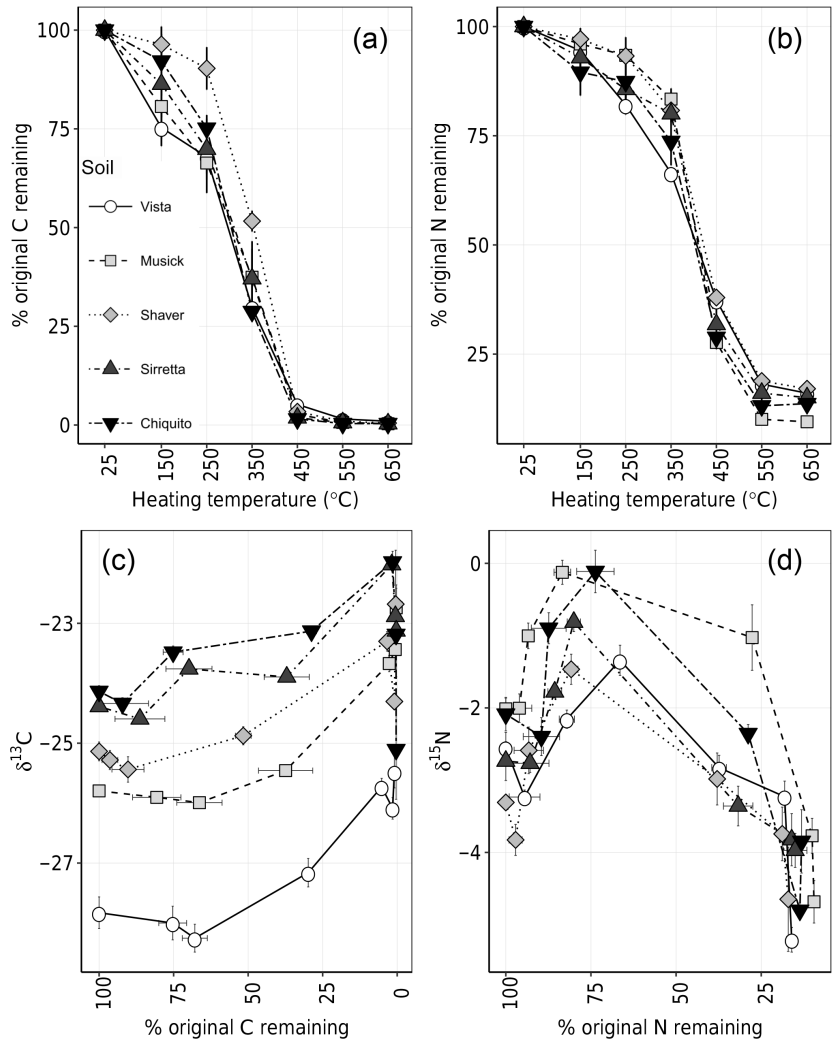

Figure 6. (a) Percentage of $\mathrm{C}$ and (b) $\mathrm{N}$ loss with heating, (c) change in $\delta^{13} \mathrm{C}$, and (d) $\delta^{15} \mathrm{~N}$ versus percent of total $\mathrm{C}$ and $\mathrm{N}$ lost from soils (error bars represent standard error, where $n=3$ ).

low-elevation soils. Enrichment of ${ }^{13} \mathrm{C}$ with heating is consistent with the loss of plant-derived $\mathrm{C}$. In addition, the fact that lipids (that have relatively more $\delta^{13} \mathrm{C}$ depleted than the woody materials) are combusted at lower temperatures than woody materials (such as cellulose and lignin) might contribute to the enrichment of $\delta^{13} \mathrm{C}$ with heating (Czimczik et al., 2002). The stable $\mathrm{C}$ and $\mathrm{N}$ isotope composition of our soils showed significant fractionation with temperature. $\delta^{13} \mathrm{C}$ values became more positive (enriched in $\delta^{13} \mathrm{C}$ ) up to $450^{\circ} \mathrm{C}$, where up to $99 \%$ of $\mathrm{C}$ was lost (Fig. 6). At higher temperatures there was a less uniform pattern among the soils. For the last $<1 \% \mathrm{C}$, Sirretta and Chiquito soils continued to be more negative (depleted in $\delta^{13} \mathrm{C}$ ) at higher temperatures, while for the rest of the soils there was a slight depletion at $550{ }^{\circ} \mathrm{C}$ followed by a slight enrichment at $650{ }^{\circ} \mathrm{C}$ (Fig. 2). The depletion of $\delta^{13} \mathrm{C}$ at 550 and $650{ }^{\circ} \mathrm{C}$ we found in this study is likely a result of SOM charring since there was little or no decrease in $\mathrm{C}$ concentration between these temperatures. In a wood charring experiment (non-oxygen atmosphere) at 150 , 340, and $480^{\circ} \mathrm{C}$, Czimczik et al. (2002) observed an enrichment of $\delta^{13} \mathrm{C}$ at $150^{\circ} \mathrm{C}$ where there was no $\mathrm{C}$ concentration change but a depletion of $\delta^{13} \mathrm{C}$ at 340 and $480^{\circ} \mathrm{C}$, with charring where the $\mathrm{C}$ concentration increased over $50 \%$ due to charring. 
Table 3. Linear correlation coefficients of changes in soil properties with changes in $\mathrm{C}$ concentration. All correlation coefficients have $p$ values $<0.01$ unless otherwise indicated.

\begin{tabular}{lrrrrrr}
\hline Soil & \multicolumn{5}{c}{ Correlation coefficient $\left(r^{2}\right)$ values } \\
\cline { 2 - 7 } & Mass loss & SSA & Aggregate stability & $\mathrm{pH}\left(\mathrm{CaCl}_{2}\right)$ & $\mathrm{CEC}$ & $\mathrm{N}$ concentration \\
\hline Vista & 0.74 & 0.73 & $0.21^{\mathrm{a}}$ & 0.77 & 0.78 & 0.89 \\
Musick & 0.89 & 0.58 & 0.77 & 0.89 & 0.96 & 0.83 \\
Shaver & 0.82 & 0.58 & 0.68 & 0.74 & 0.78 & 0.93 \\
Sirretta & 0.60 & $0.34^{\mathrm{b}}$ & 0.47 & 0.67 & 0.87 & 0.86 \\
Chiquito & 0.82 & 0.62 & 0.78 & 0.88 & 0.44 & 0.87 \\
\hline
\end{tabular}

${ }^{\mathrm{a}} p=0.078{ }^{\mathrm{b}} p=0.035$.

Fires tend to lead to enrichment of ${ }^{15} \mathrm{~N}$. This is particularly observed in soils immediately in the aftermath of fires (Boeckx et al., 2005; Grogan et al., 2000; Herman and Rundel, 1989; Huber et al., 2013), but there is limited information available on the exact temperature ranges that cause specific levels of ${ }^{15} \mathrm{~N}$ enrichment. In this study, we observed enrichment of ${ }^{15} \mathrm{~N}$ up to $350{ }^{\circ} \mathrm{C}$ and depletion after $350{ }^{\circ} \mathrm{C}$ for all soils (Fig. 2). It is likely that the continued ${ }^{15} \mathrm{~N}$ enrichment with heating is the result of fractionation due to combustion and volatilization of organic matter, which discriminate against ${ }^{15} \mathrm{~N}$. However, the exact mechanism behind continued depletion of ${ }^{15} \mathrm{~N}$ when heated above $350{ }^{\circ} \mathrm{C}$ remains unclear. One potential explanation for the ${ }^{15} \mathrm{~N}$ depletion at higher temperatures could be indiscriminate removal of $\mathrm{N}$ since higher temperatures cause the combustion and volatilization process to happen instantly, compared to charring of $\mathrm{OM}$ at lower temperatures. In a post-fire analysis of $\delta^{15} \mathrm{~N}$ on a subalpine ecosystem in Australia, Huber et al. (2013) found that the ${ }^{15} \mathrm{~N}$ enrichment of bulk surface soil (from unburnt leaves) was higher than that of the charred $\mathrm{OM}$, which was again higher than that of the ash. They attributed this difference in enrichment level to be the result of the lower heating intensity experienced by the bulk soil, which provided slower processes for greater fractionation. Conversely, higher heat intensity experienced by the ash results in full combustion of plant material, providing little opportunity for isotopic discrimination. The temperature range where we observed the depletion of ${ }^{15} \mathrm{~N}$ in our experiment corresponds with the range where a steep decline in $\mathrm{N}$ concentration happened (Fig. 6), which would be consistent with the explanation.

\section{Implication of SOM changes with heating}

The alterations in and loss of SOM are likely more important causes of soil property changes rather than alterations in soil minerals. SOM is vulnerable to temperatures, while soil minerals are only affected at much higher temperatures (Araya et al., 2016). In addition, all of the soils in our study are characterized by low clay content and low concentration of reactive minerals, but they have a high concentration of SOM, espe- cially in the topsoil, leading to strong relationships between SOM concentrations and soil physical properties.

Degradation of lignin and hemicellulose begins between 130 and $190^{\circ} \mathrm{C}$ (Chandler et al., 1983), and carbohydrate signal is completely removed from ${ }^{13} \mathrm{C}$ nuclear magnetic resonance (NMR) spectra by $350^{\circ} \mathrm{C}$. Furthermore, Knicker (2007) observed loss of stable alkyl C and carboxyl $\mathrm{C}$ at $350{ }^{\circ} \mathrm{C}$, leading to enrichment of aromatic functional groups in the remaining residue, consistent with what would be expected from incomplete combustion of OM during fires. This leads to transformation and production of charred products (Almendros et al., 2003; Knicker et al., 1996). FTIR analyses from our work showed that the aliphatic $\mathrm{O}-\mathrm{H}$ stretch peak (bands $3700-3200 \mathrm{~cm}^{-1}$ ) disappeared at temperatures above $550^{\circ} \mathrm{C}$ for all soils accompanied by nitriles or methane nitrile $\mathrm{C} \equiv \mathrm{N}$ stretch $\left(2300-2200 \mathrm{~cm}^{-1}\right)$ at temperatures above $450^{\circ} \mathrm{C}$, suggesting condensation of aromatic functional groups.

Loss of OM from soil due to combustion has multiple implications for soil physical and chemical properties. Simple linear correlation between $C$ concentration changes and other soil physical and chemical changes that we observed with heating (reported here and in Araya et al., 2016) show that more than $80 \%$ of the variability in mass loss, aggregate strength, specific surface area (SSA), $\mathrm{pH}$, cation exchange capacity (CEC), and $\mathrm{N}$ concentrations is associated with changes in $\mathrm{C}$ concentration at the different heating temperatures. Table 3 summarizes the correlation coefficients of soil property changes with change in $\mathrm{C}$ concentration. Analyses of associations between $\mathrm{C}$ concentration and several soil properties showed a linear association between $\mathrm{C}$ and $\mathrm{N}$ $\left(R^{2}>0.8\right)$, mass loss $\left(R^{2}>0.8\right.$, except for Vista and Sirretta soils), $\mathrm{pH}\left(R^{2}>0.8\right.$, except for Shaver and Sirretta), CEC $\left(R^{2}>0.7\right.$, except for Chiquito). There was a linear association between $\mathrm{C}$ concentration and aggregate strength $\left(R^{2}>\right.$ 0.7 , except for Musick and Chiquito, which had $R^{2} \sim 0.7$ ). Specific surface area showed relation with $\mathrm{C}\left(R^{2}>0.7\right.$, except for Vista and Musick).

In this study, the greatest changes in SOM occurred between the temperatures 250 and $450^{\circ} \mathrm{C}$, and we found that temperatures below $250^{\circ} \mathrm{C}$ had little effect on the quality and 
quantity of SOM. This implies that lower intensity fires, such as typical prescribed fires, where soil surface temperatures do not exceed $250{ }^{\circ} \mathrm{C}$ (Janzen and Tobin-Janzen, 2008), have minimum impact on SOM.

\subsection{Climate change implications}

Investigation of the response of climosequence soils to different heating temperatures in this study enables us to infer how changes in climate are likely to alter the effect of fires on topsoil physical and chemical properties in the long term. Along our study climosequence, we observed critical differences in response of topsoils based mostly on concentration of OM in soil and soil development stages of each soil. Soil OM concentration and composition in particular have been shown to respond to changes in precipitation amount and distribution, as is expected in the Sierra Nevada (Berhe et al., 2012b). Consequently, changes in soil C storage associated with climate change are expected to lead to different amounts of $\mathrm{C}$ loss due to fires. This is evidenced by the observed highest total mass of $\mathrm{C}$ loss from the mid-elevation Musick soil that had the highest carbon stock, compared to soils on either side of that elevation range. Anticipated changes in climate in the Sierra Nevada mountain range are expected to include upward movement of the rain-snow transition line, exposing areas that now receive most of their precipitation as snow to rainfall and associated runoff (Arnold et al., 2015, 2014; Stacy et al., 2015). Upward movement of the rain-snow transition zone under anticipated climate change scenarios and associated more intense weathering at higher elevation zones can render more $\mathrm{C}$ to be lost during fires. More than $80 \%$ of the variability in mass loss, aggregate strength, $\mathrm{SSA}, \mathrm{pH}$, $\mathrm{CEC}$, and $\mathrm{N}$ concentrations is associated with changes in $\mathrm{C}$ concentration (Table 3). Hence, as the vulnerability of these ecosystems to increased fire frequency increases due to climate change (Westerling et al., 2006), we can expect more soil $\mathrm{C}$ loss with fires, along with associated changes in soil chemical and physical properties. In particular, our findings of important changes in soil physical and chemical properties occurring between 250 and $450^{\circ} \mathrm{C}$ are important for recognizing that critical transformations of topsoil SOM are likely to occur when, as a result of climate change, systems that are adapted to low-severity fires experience medium- to highseverity fires.

The different responses of soil aggregation in our climosequence to the treatment temperatures also suggest potential loss and transformation of the physically protected $\mathrm{C}$ pool in topsoil. Degradation of aggregates during fire (Albalasmeh et al., 2013) is likely to render aggregate-protected C susceptible to potential losses through oxidative decomposition, leaching, and erosion. Moreover, in systems such as the Sierra Nevada, which are dominated by steep slopes, movement of the rain-snow transition zone upward is likely to increase proportion of precipitation that occurs as rain. The kinetic energy of raindrops and the observed increase in hy- drophobicity of soils after fires (Johnson et al., 2007, 2004) can lead to higher rates of erosional redistribution, especially for the free light fraction or particulate $\mathrm{C}$ that is not associated with soil minerals (Berhe et al., 2012a; Berhe and Kleber, 2013; McCorkle et al., 2016; Stacy et al., 2015).

\section{Conclusion}

A considerable amount of work has been published to demonstrate how fires affect OM concentration and composition in biomass. This study fills critical gaps by determining how and to what extent OM in soil experiences changes due to heating. The findings of this study also showed that changes in soil properties during heating are closely related to changes in $\mathrm{C}$ concentrations in soil. The temperatures most critical to $\mathrm{C}$ loss and alteration were found to be $250^{\circ} \mathrm{C}$, where charring of organic matter starts, and $450{ }^{\circ} \mathrm{C}$, where most of the SOM is combusted. Most soil properties exhibited a steep change in this temperature range. SOM exhibited largest change, i.e., soils became enriched in ${ }^{13} \mathrm{C}$ and ${ }^{15} \mathrm{~N}$ isotopic composition until approximately $90 \%$ of $\mathrm{C}$ and $\mathrm{N}$ was lost. At higher temperatures a slight depletion of ${ }^{13} \mathrm{C}$ and a steep depletion of ${ }^{15} \mathrm{~N}$ was observed. FTIR spectroscopy showed the reduction and disappearance of aliphatic $\mathrm{OH}$ functional groups with temperature increase and accumulation of aromatic carbon groups.

This study presented the effects of heat input on topsoil properties. The study is necessary for understanding thermally induced changes in soil properties in isolation from other variables that accompany vegetation fires, such as the addition of pyrolysis products from plants and ash and the fire-induced soil moisture dynamics. Findings from this study will contribute towards estimating the amount and rate of change in carbon and nitrogen loss and other essential soil properties that can be expected from topsoil exposure to fires of different intensities under anticipated climate change scenarios.

\section{Data availability}

The data for this article are available online at doi:10.6084/m9.figshare.4614973 (Araya et al., 2017).

\section{The Supplement related to this article is available online at doi:10.5194/soil-3-31-2017-supplement.}

Competing interests. The authors declare that they have no conflict of interest. 
Acknowledgements. The authors would like to thank Randy A. Dahlgren for providing georeferences for the study sites, background data, and for his comments on an earlier version of this paper. We thank Christina Bradley for her help and expertise in analysis of $\mathrm{C}$ and $\mathrm{N}$ and Samuel Traina for his comments on an earlier version of this paper. Funding for this work was provided by a UC Merced Graduate Research Council grant and the National Science Foundation (CAREER EAR - 1352627) award to A. A. Berhe.

Edited by: A. Jordán

Reviewed by: A. Bento-Gonçalves and three anonymous referees

\section{References}

Albalasmeh, A. A., Berli, M., Shafer, D. S., and Ghezzehei, T. A.: Degradation of moist soil aggregates by rapid temperature rise under low intensity fire, Plant Soil, 362, 335-344, doi:10.1007/s11104-012-1408-z, 2013.

Almendros, G., Gonzalez-Vila, F. J., and Martin, F.: Fire-induced transformation of soil organic matter from an oak forest: an experimental approach to the effects of fire on humic substances, Soil Sci., 149, 158-168, doi:10.1097/00010694-19900300000005, 1990.

Almendros, G., Knicker, H., and González-Vila, F. J.: Rearrangement of carbon and nitrogen forms in peat after progressive thermal oxidation as determined by solid-state ${ }^{13} \mathrm{C}$ - and ${ }^{15} \mathrm{~N}-\mathrm{NMR}$ spectroscopy, Organic Geochem., 34, 1559-1568, 2003.

Araya, S. N., Meding, M., and Berhe, A. A.: Thermal alteration of soil physico-chemical properties: a systematic study to infer response of Sierra Nevada climosequence soils to forest fires, Soil, 2, 351-366, doi:10.5194/soil-2-351-2016, 2016.

Araya, S., Berhe, A. A., and Fogel, M. L.: Analysis data from soil heating experiment, figshare, doi:10.6084/m9.figshare.4614973.v1, 2017.

Arnold, C., Ghezzehei, T. A., and Berhe, A. A.: Early spring, severe frost events, and drought induce rapid carbon loss in high elevation meadows, PloS one, 9, e106058, doi:10.1371/journal.pone.0106058, 2014.

Arnold, C., Ghezzehei, T. A., and Berhe, A. A.: Decomposition of distinct organic matter pools is regulated by moisture status in structured wetland soils, Soil Biol. Biochem., 81, 28-37, doi:10.1016/j.soilbio.2014.10.029, 2015.

Badía, D. and Martí, C.: Effect of simulated fire on organic matter and selected microbiological properties of two contrasting soils, Arid Land Research and Management, 17, 55-69, doi:10.1080/15324980301594, 2003a.

Badía, D. and Martí, C.: Plant ash and heat intensity effects on chemical and physical properties of two contrasting soils, Arid Land Research and Management, 17, 23-41, doi:10.1080/15324980301595, 2003b.

Badía, D., Martí, C., Aguirre, A. J., Aznar, J. M., González-Pérez, J. A., De la Rosa, J. M., León, J., Ibarra, P., and Echeverría, T.: Wildfire effects on nutrients and organic carbon of a Rendzic Phaeozem in NE Spain: Changes at $\mathrm{cm}$-scale topsoil, Catena, 113, 267-275, doi:10.1016/j.catena.2013.08.002, 2014.

Berhe, A. A. and Kleber, M.: Erosion, deposition, and the persistence of soil organic matter: mechanistic considerations and problems with terminology, Earth Surf. Proc. Land., 38, 908912, doi:10.1002/esp.3408, 2013.

Berhe, A. A., Harden, J. W., Torn, M. S., Kleber, M., Burton, S. D., and Harte, J.: Persistence of soil organic matter in eroding versus depositional landform positions, J. Geophys. Res.-Biogeo., 117, G02019, doi:10.1029/2011jg001790, 2012a.

Berhe, A. A., Suttle, K. B., Burton, S. D., and Banfield, J. F.: Contingency in the Direction and Mechanics of Soil Organic Matter Responses to Increased Rainfall, Plant Soil, 358, 371-383, doi:10.1007/s11104-012-1156-0, 2012b.

Boeckx, P., Paulino, L., Oyarzun, C., van Cleemput, O., and Godoy, R.: Soil $\delta^{15} \mathrm{~N}$ patterns in old-growth forests of southern Chile as integrator for N-cycling, Isot. Environ. Healt. S., 41, 249-259, doi:10.1080/10256010500230171, 2005.

Bowman, D. M. J. S., Balch, J. K., Artaxo, P., Bond, W. J., Carlson, J. M., Cochrane, M. A., D’Antonio, C. M., DeFries, R. S., Doyle, J. C., Harrison, S. P., Johnston, F. H., Keeley, J. E., Krawchuk, M. A., Kull, C. A., Marston, J. B., Moritz, M. A., Prentice, I. C., Roos, C. I., Scott, A. C., Swetnam, T. W., van der Werf, G. R., and Pyne, S. J.: Fire in the Earth System, Science, 324, 481-484, doi:10.1126/science.1163886, 2009.

Bruker Corporation: OPUS Spectroscopy Software (Version 6.5), Ettlingen, Germany, 2009.

Caldararo, N.: Human ecological intervention and the role of forest fires in human ecology, Sci. Total Environ., 292, 141-165, doi:10.1016/S0048-9697(01)01067-1, 2002.

California Department of Water Resources: Water Conditions in California, Bull. 120, Sacramento, 1952-1962.

Caprio, A. C. and Swetnam, T. W.: Historic fire regimes along an elevational gradient on the west slope of the Sierra Nevada, California, Missoula, MT, 30 March-1 April 1993, 173-179, 1995.

Carroll, E. M., Miller, W. W., Johnson, D. W., Saito, L., Qualls, R. G., and Walker, R. F.: Spatial analysis of a large magnitude erosion event following a Sierran wildfire, J. Environ. Qual., 36, 1105-1111, doi:10.2134/jeq2006.0466, 2007.

Certini, G.: Effects of fire on properties of forest soils: a review, Oecologia, 143, 1-10, doi:10.1007/s00442-004-1788-8, 2005.

Chandler, C., Cheney, P., Thomas, P., Trabaud, L., and William, D.: Fire effects on soil, water and air, in: Fire in Forestry. Vol I: Forest fire behaviour and effects, John Wiley Sons, New York, 1983.

Czimczik, C. I., Preston, C. M., Schmidt, M. W. I., Werner, R. A., and Schulze, E.-D.: Effects of charring on mass, organic carbon, and stable carbon isotope composition of wood, Organic Geochem., 33, 1207-1223, doi:10.1016/S0146-6380(02)001377, 2002.

Dahlgren, R. A., Boettinger, J. L., Huntington, G. L., and Amundson, R. G.: Soil development along an elevational transect in the western Sierra Nevada, California, Geoderma, 78, 207-236, doi:10.1016/S0016-7061(97)00034-7, 1997.

DeBano, L. F.: The effect of fire on soil properties, Boise, ID, 1012 April, 151-156, 1990-1991.

DeBano, L. F.: The role of fire and soil heating on water repellency in wildland environments: a review, J. Hydrol., 231, 195-206, doi:10.1016/S0022-1694(00)00194-3, 2000.

DeBano, L. F., Dunn, P. H., and Conrad, C. E.: Fire's effect on physical and chemical properties of Chaparral soils, USDA Forest Service General Technical Report WO-3, 1977.

DeBano, L. F., Neary, D. G., and Ffolliott, P. F.: Fire's effect on ecosystems John Wiley \& Sons, Inc., New York, USA, 1998. 
de la Rosa, J. M. and Knicker, H.: Bioavailability of N released from $\mathrm{N}$-rich pyrogenic organic matter: An incubation study, Soil Biol. Biochem., 43, 2368-2373, doi:10.1016/j.soilbio.2011.08.008, 2011.

Dennis, E. I., Usoroh, A. D., and Ijah, C. J.: Soil properties dynamics induced by passage of fire during agricultural burning, International Journal of Advance Agricultural Research, 1, 4352, doi:10.9734/IJPSS/2013/3121, 2013.

Ellerbrock, R. H. and Gerke, H. H.: Characterization of organic matter composition of soil and flow path surfaces based on physicochemical principles - a review, in: Advances in Agronomy, edited by: Sparks, D. L., Academic Press, Burlington, 2013.

FAO: State of the world's forest Food and Agricultural Organization of the United Nations, Rome, Italy, 2005.

Fernández, I., Cabaneiro, A., and Carballas, T.: Organic matter changes immediately after a wildfire in an Atlantic forest soil and comparison with laboratory soil heating, Soil Biol. Biochem., 29, 1-11, doi:10.1016/S0038-0717(96)00289-1, 1997.

Fernández, I., Cabaneiro, A., and Carballas, T.: Thermal resistance to high temperatures of different organic fractions from soils under pine forests, Geoderma, 104, 281-298, doi:10.1016/S00167061(01)00086-6, 2001.

Fisher, R. F. and Binkley, D.: Ecology and management of forest soils, 3, John Wiley and Sons, Inc., New York, USA, 2000.

Frandsen, W. H. and Ryan, K. C.: Soil moisture reduces belowground heat flux and soil temperatures under a burning fuel pile, Can. J. Forest Res., 16, 244-248, doi:10.1139/x86-043, 1986.

Giovannini, G.: The effect of fire on soil quality, in: Soil Erosion and Degradation as a Consequence of Forest Fires, edited by: Sala, M. and Rubio, J. L., Geoforma Ediciones, Logrono, 1994.

Giovannini, G., Lucchesi, S., and Giachetti, M.: Effect of heating on some physical and chemical parameters related to soil aggregation and erodibility, Soil. Sci., 146, 255-261, doi:10.1097/00010694-198810000-00006, 1988.

González-Pérez, J., González-Vila, F., Almendros, G., and Knicker, H.: The effect of fire on soil organic matter - a review, Environ. Int., 30, 855-870, doi:10.1016/j.envint.2004.02.003, 2004.

Grogan, P., Burns, T. D., and Chapin III, F. S.: Fire effects on ecosystem nitrogen cycling in a Californian bishop pine forest, Oecologia, 122, 537-544, doi:10.1007/s004420050977, 2000.

Harradine, F. and Jenny, H.: Influence of parent material and climate on texture and nitrogen and carbon contents of virgin California soils: texture and nitrogen contents of soils, Soil. Sci., 85, 235243, 1958

Harrison, S. P., Marlon, J. R., and Bartlein, P. J.: Fire in the Earth System, in: Changing Climates, Earth Systems and Society, edited by: Dodson, J., International Year of Planet Earth, Springer, New York, 2010.

Herman, D. J. and Rundel, P. W.: Nitrogen isotope fractionation in burned and unburned Chaparral soils, Soil Sci. Soc. Am. J., 53, 1229-1236, 1989.

Huber, E., Bell, T. L., and Adams, M. A.: Combustion influences on natural abundance nitrogen isotope ratio in soil and plants following a wildfire in a sub-alpine ecosystem, Oecologia, 173, 1063-1074, doi:10.1007/s00442-013-2665-0, 2013.

Huntington, G. L.: The effect of vertical zonality on clay content in residual granitic soils of the Sierra Nevada mountains, University of California, Berkeley, 1954.
Janzen, C. and Tobin-Janzen, T.: Microbial communities in fireaffected soils, in: Microbiology of Extreme Soils, edited by: Dion, P. and Nautiyal, C. S., Soil Biology, 13, Springer-Verlag Berlin Heidelberg, 2008.

Jenny, H., Gessel, S. P., and Bingham, F. T.: Comparative study of decomposition rates of organic matter in temperate and tropical regions, Soil Sci., 68, 419-432, 1949.

Johnson, D., Murphy, J., Walker, R., Glass, D., and Miller, W.: Wildfire effects on forest carbon and nutrient budgets, Ecol. Eng., 31, 183-192, 2007.

Johnson, D. W., Susfalk, R. B., Caldwell, T. G., Murphy, J. D., Miller, W. W., and Walker, R. F.: Fire Effects on Carbon and Nitrogen Budgets in Forests, Water Air Soil Poll., 4, 263-275, doi:10.1023/B:WAFO.0000028359.17442.d1, 2004

Kaiser, M., Kleber, M., and Berhe, A. A.: How air-drying and rewetting modify soil organic matter characteristics: An assessment to improve data interpretation and inference, Soil Biol. Biochem., 80, 324-340, doi:10.1016/j.soilbio.2014.10.018, 2015.

Kavdır, Y., Ekinci, H., Yüksel, O., and Mermut, A. R.: Soil aggregate stability and ${ }^{13} \mathrm{C}$ CP/MAS-NMR assessment of organic matter in soils influenced by forest wildfires in Çanakkale, Turkey, Geoderma, 129, 219-229, doi:10.1016/j.geoderma.2005.01.013, 2005.

Knicker, H.: How does fire affect the nature and stability of soil organic nitrogen and carbon? A review, Biogeochemistry, 85, 91 118, doi:10.1007/s10533-007-9104-4, 2007.

Knicker, H.: "Black nitrogen" - an important fraction in determining the recalcitrance of charcoal, Org. Geochem., 41, 947-950, doi:10.1016/j.orggeochem.2010.04.007, 2010.

Knicker, H., Almendros, G., González-Vila, F. J., Martín, F., and Lüdemann, H.-D.: ${ }^{13} \mathrm{C}$-and ${ }^{15} \mathrm{~N}-\mathrm{NMR}$ spectroscopic examination of the transformation of organic nitrogen in plant biomass during thermal treatment, Soil Biol. Biochem., 28, 1053-1060, 1996.

Knicker, H., Gonzalezvila, F., Polvillo, O., Gonzalez, J., and Almendros, G.: Fire-induced transformation of $\mathrm{C}$ - and $\mathrm{N}$ - forms in different organic soil fractions from a Dystric Cambisol under a Mediterranean pine forest, Soil Biol. Biochem., 37, 701-718, doi:10.1016/j.soilbio.2004.09.008, 2005.

Mataix-Solera, J., Cerda, A., Arcenegui, V., Jordan, A., and Zavala, L. M.: Fire effects on soil aggregation: A review, Earth-Sci. Rev., 109, 44-60, doi:10.1016/j.earscirev.2011.08.002, 2011.

McCorkle, E. P., Berhe, A. A., Hunsaker, C. T., McFarlane, K. J., Johnson, D., Fogel, M. L., and Hart, S. C.: Tracing the source of soil organic matter eroded from temperate forested catchments using carbon and nitrogen isotopes, Chem. Geol., 445, 172-184, doi:10.1016/j.chemgeo.2016.04.025, 2016.

McKelvey, K. S., Skinner, C. N., Chang, C.-R., Erman, D. C., Husari, S. J., Parsons, D. J., Wagtendonk, J. W. V., and Weatherspoon, C. P.: An overview of fire in the Sierra Nevada, Davis, California, 37, 1996.

National Interagency Fire Center: available at: https://www.nifc. gov/fireInfo/fireInfo_statistics.html, last access: 5 June 2015.

Neary, D. G., Klopatek, C. C., DeBano, L. F., and Ffolliott, P. F.: Fire effects on belowground sustainability: a review and synthesis, Forest Ecol. Manage., 122, 51-71, doi:10.1016/S03781127(99)00032-8, 1999.

Parikh, S. J., Goyne, K. W., Margenot, A. J., Mukome, F. N. D., and Calderón, F. J.: Soil chemical insights provided through vibra- 
tional spectroscopy, in: Advances in Agronomy, edited by: Donald, L. S., Academic Press, 2014.

Parsons, A., Robichaud, P. R., Lewis, S. A., Napper, C., and Clark, J.: Field guide for mapping post-fire soil burn severity, U.S. Department of Agriculture, Forest Service, Rocky Mountain Research Station, Fort Collins, CO, 2010.

Pechony, O. and Shindell, D. T.: Driving forces of global wildfires over the past millennium and the forthcoming century, P. Natl. Acad. Sci. USA, 107, 19167-19170, doi:10.1073/pnas.1003669107, 2010.

Rasmussen, C., Matsuyama, N., Dahlgren, R. A., Southard, R. J., and Brauer, N.: Soil Genesis and Mineral Transformation Acrossan Environmental Gradient on Andesitic Lahar, Soil Sci. Soc. Am. J., 71, 225-237, doi:10.2136/sssaj2006.0100, 2007.

R Core Team: R: A Language and Environment for Statistical Computing, R Foundation for Statistical Computing, Vienna, Austria, 2014.

Reeves III, J. B.: Mid-infrared diffuse reflectance spectroscopy: is sample dilution with $\mathrm{KBr}$ necessary, and if so, when?, Am. Lab., 35, 24-28, 2003.

Rein, G., Cleaver, N., Ashton, C., Pironi, P., and Torero, J. L.: The severity of smouldering peat fires and damage to the forest soil, Catena, 74, 304-309, doi:10.1016/j.catena.2008.05.008, 2008.

Santos, F., Russell, D., and Berhe, A. A.: Thermal alteration of water extractable organic matter in climosequence soils from the Sierra Nevada, California, J. Geophys. Res.-Biogeo., 121, 28772885, doi:10.1002/2016JG003597, 2016.

Singh, N., Abiven, S., Torn, M. S., and Schmidt, M. W. I.: Fire-derived organic carbon in soil turns over on a centennial scale, Biogeosciences, 9, 2847-2857, doi:10.5194/bg-9-28472012, 2012.

Six, J., Elliott, E. T., and Paustian, K.: Soil macroaggregate turnover and microaggregate formation: a mechanism for $\mathrm{C}$ sequestration under no-tillage agriculture, Soil Biol. Biochem., 32, 2099-2103, doi:10.1016/S0038-0717(00)00179-6, 2000.

Skinner, C. N. and Chang, C.-R.: Fire Regimes, Past and Present, in: Sierra Nevada Ecosystem Project, Final Report to Congress, Vol. II, Assessment and Scientific Basis for management Options, Davis: University of California, Center for Wate rand Wildland Resoures, 1996.

Soto, B., Benito, E., Basanta, R., and Díaz-Fierros, F.: Influence of antecedent soil moisture on pedological effects of fire, in: Soil Erosion and Degradation as a Consequence of Forest Fires, edited by: Sala, M. and Rubio, J. L., Geoforma Ed., Logroño, Spain, 1991.
Stacy, E. M., Hart, S. C., Hunsaker, C. T., Johnson, D. W., and Berhe, A. A.: Soil carbon and nitrogen erosion in forested catchments: implications for erosion-induced terrestrial carbon sequestration, Biogeosciences, 12, 4861-4874, doi:10.5194/bg-124861-2015, 2015.

Steward, F. R., Peter, S., and Richon, J. B.: A Method for Predicting the Depth of Lethal Heat Penetration into Mineral Soils Exposed to Fires of Various Intensities, Can. J. Forest Res., 20, 919-926, doi:10.1139/X90-124, 1990.

Terefe, T., Mariscal-Sancho, I., Peregrina, F., and Espejo, R.: Influence of heating on various properties of six Mediterranean soils: a laboratory study, Geoderma, 143, 273-280, doi:10.1016/j.geoderma.2007.11.018, 2008.

Trumbore, S. E., Chadwick, O. A., and Amundson, R.: Rapid exchange between soil carbon and atmospheric carbon dioxide driven by temperature change, Science, 272, 393-396, doi:10.1126/science.272.5260.393, 1996.

Ulery, A. L. and Graham, R. C.: Forest-fire effects on soil color and texture, Soil Sci. Soc. Am. J., 57, 135-140, doi:10.2136/sssaj1993.03615995005700010026x, 1993.

US Geological Survey: NLCD 2011 Land Cover (2011th Edn., ammended 2014), Sioux Falls, SD, USA, 2014.

van Wagtendonk, J. W. and Fites-Kaufman, J. A.: Sierra Nevada Bioregion, in: Fire in California's Ecosystems, edited by: Sugihara, N. G., van Wagtendonk, J. W., Shaffer, K. E., and Thode, A. E., University of California Press, Berkeley, CA, USA, 2006.

Varela, M. E., Benito, E., and Keizer, J. J.: Effects of wildfire and laboratory heating on soil aggregate stability of pine forests in Galicia: the role of lithology, soil organic matter content and water repellency, Catena, 83, 127-134, doi:10.1016/j.catena.2010.08.001, 2010.

Westerling, A. L., Hidalgo, H. G., Cayan, D. R., and Swetnam, T. W.: Warming and earlier spring increase western U.S. forest wildfire activity, Science, 313, 940-943, doi:10.1126/science.1128834, 2006.

Zavala, L. M., Granged, A. J. P., Jordán, A., and Bárcenas-Moreno, G.: Effect of burning temperature on water repellency and aggregate stability in forest soils under laboratory conditions, Geoderma, 158, 366-374, doi:10.1016/j.geoderma.2010.06.004, 2010 . 